\title{
Growth of a high-elevation large inland lake, associated with climate change and permafrost degradation in Tibet
}

\author{
J. Liu ${ }^{1}$, S. Kang ${ }^{1,3}$, T. Gong ${ }^{2}$, and A. Lu $^{3}$ \\ ${ }^{1}$ Nam Co Monitoring and Research Station for Multisphere Interaction, Institute of Tibetan Plateau Research, Chinese \\ Academy of Sciences, Beijing 100085, China \\ ${ }^{2}$ Hydrology and Water Resources Bureau of Tibet, Lhasa 850000, China \\ ${ }^{3}$ Key Laboratory of Cryosphere and Environment, Cold and Arid Regions Environmental and Engineering Institute, Chinese \\ Academy of Sciences, Lanzhou 730000, China
}

Received: 5 April 2009 - Published in Hydrol. Earth Syst. Sci. Discuss.: 7 August 2009

Revised: 14 December 2009 - Accepted: 23 December 2009 - Published: 12 March 2010

\begin{abstract}
This study analyzed satellite images and long term climate variables from a high-elevation meteorological station $(4730 \mathrm{~m})$ and streamflow records to examine hydrological response of Nam Co Lake $(4718 \mathrm{~m})$, the largest lake on the Tibetan Plateau, over the last 50 years. The results show the lake area extended by $51.8 \mathrm{~km}^{2}$ (2.7\% of the total area) when compared with the area in 1976. This change is associated with an annual precipitation increase of $65 \mathrm{~mm}(18.6 \%)$, annual and winter mean temperature increases of $0.9^{\circ} \mathrm{C}$ and $2.1{ }^{\circ} \mathrm{C}$ respectively, an annual runoff increase of $20 \%$ and an annual pan evaporation decrease of about $2 \%$, during the past 20 years. The year of the change point in annual precipitation, air temperature, annual pan evaporation and runoff occurred in 1971, 1983, 1997 and 1997, respectively. The timing of the lake growth corresponds with the abrupt increase in annual precipitation and runoff since the mid-1990s.
\end{abstract}

\section{Introduction}

Lake systems with permafrost cover are highly sensitive to changes in air temperature, snowmelt and soil frost (Marsh and Neumann, 2001; Duguay et al., 2006; Gibson et al., 2006; Mielko and Woo, 2006). Degradation to the permafrost can speed up water transfer, increase soil moisture, and improve agricultural productivity and the environment (IPCC, 2001; Qin et al., 2005). Climate change has significant implications for water resources and the ecoenvironment in cold and arid regions, such as northwest and

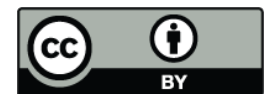

Correspondence to: J. Liu

(jsliu@itpcas.ac.cn) northeast China, and in particular, the Tibetan Plateau (Liu et al., 1999; Wang et al., 1996; Zhou et al., 1996). Much evidence suggests that the regional climate in northwest China has shifted from a warm-dry to a warm-wet regime (Shi et al., 2003).

The Tibetan Plateau, with an average altitude more than $4000 \mathrm{~m}$ above sea level (a.s.l.), is the highest plateau in the world, and permafrost covers about $67 \%$ of the plateau (Zhou et al., 2000). There are more than 1500 lakes in the area, $60 \%$ of which are inland lakes ranging in size from $0.01 \mathrm{~km}^{2}$ to $4000 \mathrm{~km}^{2}$ (Wang et al., 1998). Previous research suggests that warming and wetting during winter and spring has occurred in Tibet since the late 1980s (Du, 2001; Wang et al., 2005; Chen et al., 2006). Other studies demonstrated that winter warming in high latitudes and the high elevation permafrost region in northeastern China has led to higher ground temperature and considerable seasonal infiltration of meltwater and surface flow (Liu et al., 2003a, b, 2007). However, no studies have been conducted to investigate the relationships between climatic variables, permafrost cover, and water balance of high- elevation inland lakes due to the lack of glaciological, geocryological and hydrological information. The high-elevation inland lakes in the Tibetan Plateau are representative of the climatic regime in the region, and have been subject to few human interventions (i.e., no irrigation or hydroelectric development). A monitoring and research station for multispheric interactions was established at Nam Co Lake (Nam Co) by the Institute of Tibetan Plateau Research, Chinese Academy of Sciences in 2005. The objective of this study is to quantify the response of Nam Co to climate, hydrology and permafrost changes and to investigate the interactions between hydrological and climatic processes in the highlands of the world.

Published by Copernicus Publications on behalf of the European Geosciences Union. 


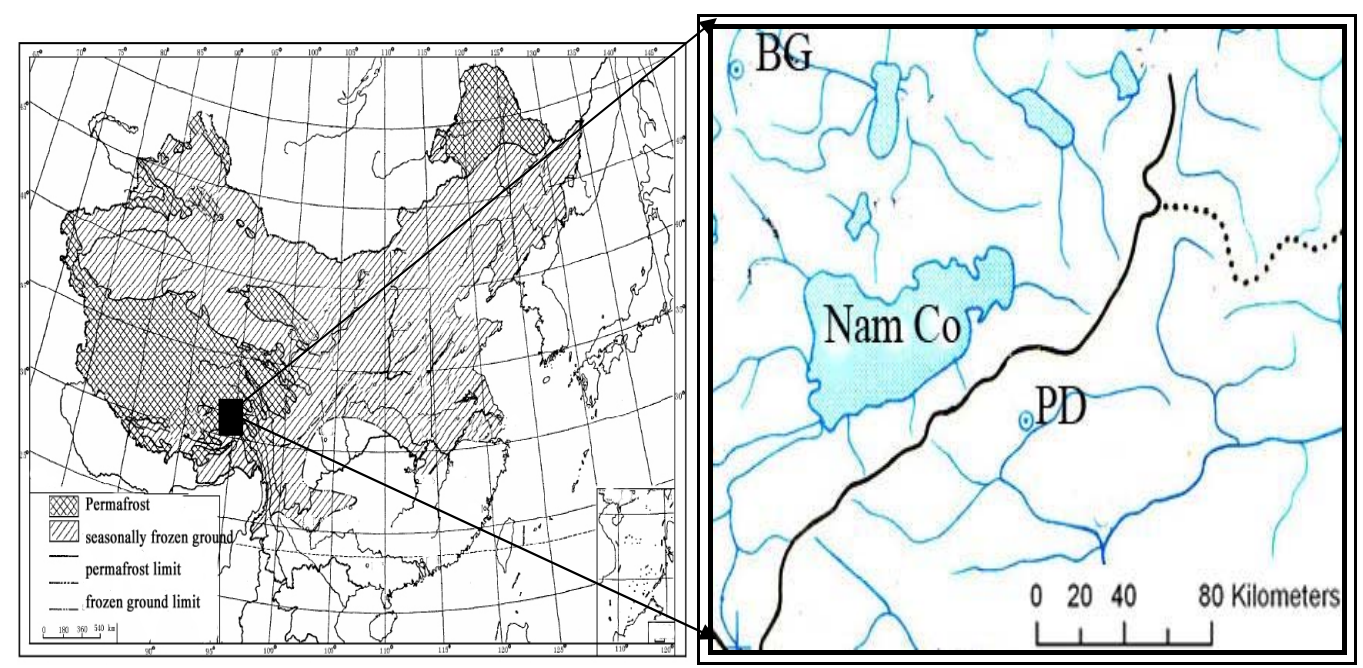

Fig. 1. Permafrost distribution and the surrounding meteorological and gauging station location of Lake Nam Co on the Tibetan Plateau(meteorological station is at Bange (BG) county, and a gauge station at Pangdo (PD) of the upper Lhasa River on right graph).

\section{Study area, data and methodology}

Figure 1 shows maps of permafrost regions in China and the location of the largest high-elevation inland lake, Nam Co $\left(30^{\circ} 30^{\prime}-30^{\circ} 55^{\prime} \mathrm{N}, 90^{\circ} 16^{\prime}-91^{\circ} 03^{\prime} \mathrm{E}, 4720 \mathrm{~m}\right.$ a.s.l.), near the Bange (denoted by BG) in the central Tibet. The lake has surface and drainage areas of $1940 \mathrm{~km}^{2}$ and $10610 \mathrm{~km}^{2}$, respectively, and its elevation ranges from the southeastern headwater of Mount Nyainqentanglha at $7270 \mathrm{~m}$ to the lake surface of $4718 \mathrm{~m}$, with an average elevation of $5230 \mathrm{~m}$. Nam Co is located in the discontinuous permafrost at lower elevations and in the continuous permafrost at higher elevations. The lower limit of the permafrost is $4800 \mathrm{~m}$, and the mean thickness of the active layer is about $210 \mathrm{~cm}$ under a cold continental climate (Zhou et al., 2000). There are more than one hundred glaciers along the northern slope of the Nyainqentanglha Mountains covering a total area of $179.74 \mathrm{~km}^{2}$ and the glaciers contribute about $10 \%$ of inflow into the lake (www.lake.csdb.cn).

The nearest meteorological station is located in BG $\left(31^{\circ} 23^{\prime} \mathrm{N}, 90^{\circ} 01^{\prime} \mathrm{E}, 4700 \mathrm{~m}\right.$ a.s.l.) and has long term records of air temperature, precipitation, pan evaporation and frost depth of soils for the last 50 years (1956-2005). The mean annual temperature at $\mathrm{BG}$ is $-1.1^{\circ} \mathrm{C}$ with the lowest air temperature in January at $-11.8^{\circ} \mathrm{C}$. The mean annual precipitation is around $310 \mathrm{~mm}$, of which $85-90 \%$ falls in summer during the Indian monsoon period. In the cold season from October to April, snowpacks exist and periodic events of soil freeze and thaw occur frequently at higher elevations. The lake is recharged by rainfall in summer, snowmelt in both spring and autumn, and subsurface flow in winter. Due to the lack of hydrological observations surrounding the lake, the discharge data from the neighboring Lhasa River at the upstream gauging station $\mathrm{PD}\left(30^{\circ} 8^{\prime} \mathrm{N}, 91^{\circ} 21^{\prime} \mathrm{E}, 4150 \mathrm{~m}\right.$ a.s.l. $)$ were used in the analyses. The data covers the period of 1976 to 2003. Because of the higher elevation of Nam Co compared with the Lhasa River, which results in lower air temperature, lower evaporation and weak infiltration over frozen ground, surface runoff at Nam Co should be larger, or have at least the same surface conditions, than that measured for the Lhasa River.

Remote sensing is an effective approach for monitoring changes in water area and landform. The Landsat-TM images, with a resolution of $30 \mathrm{~m}$, were used to study the lake surface area in the 1990s. China and Brazil have jointly launched satellites named CBRES-1 and CBRES-2 in 1999 and 2003, respectively. The image data for lake areas were obtained from the CBERS-1 and -2. The images were taken every October from 2001-2005, the spatial resolution is $20 \mathrm{~m}$ at bands 2, 3 and 4, and the lake information was determined at low brightness. Initially, digital images were processed with standard procedures including geo-referencing, radiometric correction and enhancement. Each scene was then geo-referenced and identified using 20 ground control points and topographic maps at 1:50000. The corrected image was used as the reference for image-to-image registration of all other band images. Field surveys were conducted in 2005 and 2006, guided by a GPS to aid the computer mapping. Finally, all data were projected into a uniform projection system with the WGS-84.

The Mann-Kendall (M-K) nonparametric trend test was used in this study (Mann, 1945; Kendall, 1975). Detailed descriptions of the M-K test can be found in Kundzewicz and Robson (2004) and Burn et al. (2004). The procedure starts with an evaluation of trends occurring in the hydrometeorological variables for each station. The results of the trend test can be used to determine whether the observed time series exhibits trends that are greater than those expected to occur by chance. All the trend results in this work were evaluated at significance levels of $99 \%, 95 \%$ and $90 \%$. 
Table 1. Hydrological parameters and area variability of Nam Co Lake.

\begin{tabular}{cccccc}
\hline $\begin{array}{c}\text { Lake area } \\
\left(\mathrm{km}^{2}\right)^{\bullet}\end{array}$ & $\begin{array}{c}\text { lake area } \\
\left(\mathrm{km}^{2}\right)^{\bullet}\end{array}$ & $\begin{array}{c}\text { lake area } \\
\left(\mathrm{km}^{2}\right)^{\mathbf{\Lambda}}\end{array}$ & $\begin{array}{c}\text { lake area } \\
\left(\mathrm{km}^{2}\right)^{*}\end{array}$ & $\begin{array}{c}\text { lake area } \\
\left(\mathrm{km}^{2}\right)^{*}\end{array}$ & $\begin{array}{c}\text { Variation } \\
(\%)\end{array}$ \\
\hline $\begin{array}{c}1941.3 \\
1970\end{array}$ & $\begin{array}{c}1933.7 \\
1976\end{array}$ & $\begin{array}{c}1962.8 \\
1991\end{array}$ & $\begin{array}{c}1981.0 \\
2000\end{array}$ & $\begin{array}{c}1993.1 \\
2006\end{array}$ & 1.96 \\
\hline
\end{tabular}

- from China Lake Database, 1998

$\Delta$ from Landsat-TM images

* imagery from CBERS-1 and CBERS-2.

In order to search for change points in trends with time, sequential values for Forward $\_u$ and Backward_ $u$ from the progressive analysis created by Sneyers (1990) and Mitchell et al. (1996) based on the M-K test were applied. The Forward $\_u$ is a standardized variable that has zero mean and unit standard deviation. Therefore, its sequential behavior fluctuates around zero. The Forward $\_$is the same as the $z$ values that are found from the first to last data point. This test considers the relative values of all terms in the time series $\left(x_{1}\right.$, $\left.x_{2}, \ldots, x_{\mathrm{T}}\right)$. The following steps are applied in sequence:

i The magnitudes of $x_{j}$ time series, $(j=1,2, \ldots, \mathrm{T})$ are compared with $x_{k}(k=1,2, \ldots, \mathrm{T}-1)$. In each comparison, the number of cases $x_{j}>x_{k}$ is counted and denoted by $n_{j}$.

ii The test statistic $t$ is then given by equation:

$$
\mathrm{t}_{j}=\sum_{1}^{j} n_{i}
$$

iii The mean and variance are:

$$
\mathrm{E}(\mathrm{t})=\frac{n(n-1)}{4}
$$

And

$$
\operatorname{Var}\left(\mathrm{t}_{j}\right)=\frac{j(j-1)(2 j+5)}{72}
$$

iv The sequential values of the statistic $u(\mathrm{t})$ for Forward $\_u$ are then calculated by:

$$
u(\mathrm{t})=\frac{\mathrm{t}_{j}-\mathrm{E}(\mathrm{t})}{\sqrt{\operatorname{Var}\left(\mathrm{t}_{j}\right)}}
$$

The same principle is applied to the retrograde series. Therefore, the $u(\mathrm{t})$ values of the Backward $\_u$ are computed backward, starting from the end of the series. The intersection of the curves showing the Forward $\_u$ and Back-ward $\_u$ represents the time when a trend or change starts.

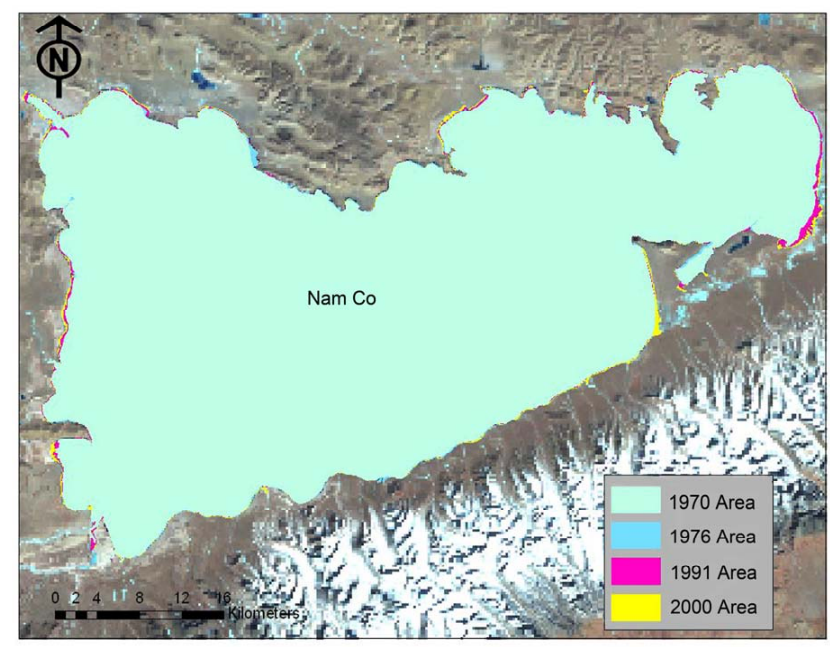

Fig. 2. The lake area changes of Nam Co during 1970 to 2000.

\section{Lake growth and hydroclimatological regime}

\subsection{Lake growth}

Table 1 and Fig. 2 show changes in the Nam Co area for the last three decades. Most of the images combined in Fig. 2 were taken in October 1970, 1990, 2001-2005 when the lake water level was the highest. An important principle in choosing a satellite image is the consistency in the imaging date with the same weather conditions. There were no noticeable changes in the lake area before 1998 according to local people through field surveys during 2004-2006. Statistical analyses indicate that comparing the lake area in 1976 with the lake area in 2005, the area has enlarged by $38.6 \mathrm{~km}^{2}(1.8 \%)$. It is clear that the expansion of the lake area has accelerated in the last decade, especially in the past five years.

\subsection{Meteorological variables}

Meteorological data from BG were investigated for trends over the last 50 years, with results shown in Table 2 and Fig. 3. The monthly mean temperatures showed strong upward trends for the cold months from October to March, increasing by $0.6^{\circ} \mathrm{C}$ in October, $2.1^{\circ} \mathrm{C}$ in November, $2.0^{\circ} \mathrm{C}$ in December, $1.6^{\circ} \mathrm{C}$ in January, $1.3{ }^{\circ} \mathrm{C}$ in February and $1.4^{\circ} \mathrm{C}$ in March, since the 1980s. This resulted in much of the $0.9^{\circ} \mathrm{C}$ increase in the annual mean temperature in the 1990s. No significant trends were found for temperature during the months of summer and autumn. This suggests that climate warming is mainly associated with temperature increases in winter season.

The change point tests, however, reveal that far from there being a steady rise in winter temperatures, the time series for several months and the annual average include abrupt changes that started in years ranging from 1966 to 1983 as shown in Fig. 4. The effect of these changes can be demonstrated with anomaly curves and variation bars of the 
Table 2. Change point (Y) determined by Mann-Kendall test of abrupt change and slope $(\beta)$ in upward trends of temperature $\left(T\right.$ in $\left.{ }^{\circ}\right)$, precipitation $(P$ in $\mathrm{mm})$, annual pan evaporation $\left(\mathrm{E}_{a}\right.$ in $\left.\mathrm{mm}\right)$ and discharge $\left(Q\right.$ in $\left.\mathrm{m}^{3} / \mathrm{s}\right)$ with confidence levels $(\alpha)$.

\begin{tabular}{cccccccccccccc}
\hline$\beta / \alpha$ & Jan & Feb & Mar & Apr & May & Jun & Jul & Aug & Sep & Oct & Nov & Dec & Year \\
\hline$T$ & $0.075^{*}$ & $0.075^{*}$ & $0.071^{*}$ & NT & NT & NT & NT & NT & NT & $0.042^{+}$ & $0.075^{*}$ & $0.071^{*}$ & $0.038^{*}$ \\
Y & 1970 & 1966 & 1972 & NT & NT & NT & NT & NT & NT & 1982 & 1973 & 1967 & 1983 \\
$P$ & $0.031^{+}$ & $0.024^{+}$ & NT & $0.107^{+}$ & $0.654^{+}$ & NT & NT & NT & $0.500^{+}$ & NT & NT & NT & $2.40^{*}$ \\
Y & 1997 & 1967 & NT & 1976 & 1981 & NT & NT & NT & 1979 & NT & NT & NT & 1969 \\
$\mathrm{E}_{a}$ & NT & NT & NT & NT & NT & $-1.27^{+}$ & $-0.60^{+}$ & NT & $-0.78^{+}$ & NT & NT & NT & $-5.21^{+}$ \\
Y & NT & NT & NT & NT & NT & 2000 & 2000 & NT & 1995 & NT & NT & NT & 1996 \\
$Q$ & $0.070^{*}$ & $0.080^{*}$ & $0.078^{*}$ & $0.103^{+}$ & NT & NT & NT & NT & $1.31^{*}$ & NT & NT & $0.072^{+}$ & $0.331^{+}$ \\
Y & 1983 & 1985 & 1985 & 1996 & NT & NT & NT & NT & 1996 & NT & NT & 1996 & 1997 \\
\hline
\end{tabular}

$T$ and $P$ are air temperatures and precipitation, respectively at BG station from 1956 to 2005; $Q$ are monthly discharges from 1976 to 2005 ; ${ }^{*}$ and ${ }^{+}$indicate the statistical significance $\alpha$ at 0.01 and 0.05 respectively; NT indicates no trend; Y is the detected year of the change point.

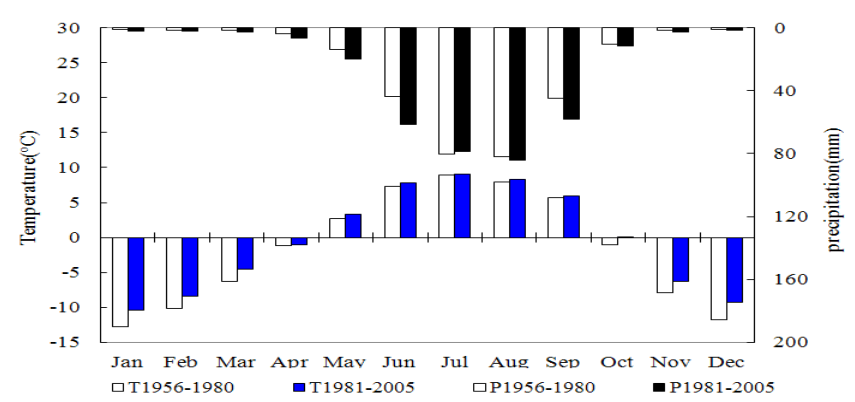

Fig. 3. Bar graphs comparing the monthly variations of air temperature $(T-)$ and precipitation $(P-)$ at BG during the 1956-1980 and 19981-2005.

annual and monthly temperature and precipitation before and after the 1990s (Fig. 5). The average annual temperature in recent decades was about $0.91^{\circ} \mathrm{C}$ higher than during 1956 to 1980, and the highest annual temperature occurred in 1999. In fact, annual temperatures during 1995 to 2005 were all higher than the long-term annual average.

Figure 5 and Table 2 also illustrate the annual precipitation anomaly at BG. The data indicate a dramatic increase from 1956 to the mid-1980s, followed by a slow increase since 1995. The annual precipitation in recent decades was $55.4 \mathrm{~mm}$ (about $18.6 \%$ ) above the annual average during 1956-1990, and the maximum annual precipitation was $446.1 \mathrm{~mm}$ in 2003 . The monthly precipitation increased mainly in May, June, and September by $9.4 \mathrm{~mm}(60 \%)$ $22.1 \mathrm{~mm}(46 \%)$, respectively, since the 1990s when compared with the period of 1956 to 1990 . Snowfall in the cold season of October to January also increased substantially, by about 30\%-100\% above the mean before the 1990s. Meanwhile, the annual pan evaporation has decreased since 1996 caused by reductions in monthly pan evaporation for June, July and September, respectively since 2000 and 1995. Overall, the regional climate in the inland lake has shifted into a warmer and wetter pattern since the mid-1990s.
Du et al. (2001, 2004) analyzed the climatic trend of both air temperature and precipitation using long-term (1961 and 1971-2000) data from 40 meteorological stations across the Tibetan Plateau, and found significant increases in both the mean annual and winter air temperature with a rate of $0.026^{\circ} \mathrm{C}$ per year and $0.06^{\circ} \mathrm{C}$ per year respectively. They also found precipitation was increasing at a rate of $19.9 \mathrm{~mm}$ per decade in most areas of Tibet (except the western areas), particularly since the mid-1980's. Furthermore, Chen et al. (2006) analyzed the potential evapotranspiration at 101 stations over the Tibetan Plateau and found the annual evapotranspiration ratio decreased by $13.1 \mathrm{~mm}$ per decade, with decreasing rates being more pronounced in winter and spring ( $80 \%$ of all stations) compared with summer and autumn (58\% of all stations).

Singh and Sontakke had documented the instrumental periodic fluctuations of important climatic parameters like rainfall amounts (1829-1999), severe rainstorms (1880-1996) and temperature (1876-1997) for the Indo- Gangetic Plains region (IGPR). The summer monsoon rainfall in the western IGPR shows increasing trend $(170 \mathrm{~mm}$ per century, significant at $1 \%$ level) from 1900, while it shows a decreasing trend ( $5 \mathrm{~mm}$ per century, not significant) from 1939 over the central IGPR. There is a decreasing trend $(50 \mathrm{~mm}$ per century, not significant) during 1900-1984 and an insignificant increasing trend ( $480 \mathrm{~mm}$ per century, not significant) during 1984-1999 over the eastern IGPR (2002). Broadly it is inferred that there has been a westward shift in rainfall activities over the IGPR. Analysis suggests a westward shift in the occurrence of severe rainstorms also. These spatial changes in rainfall activities are attributed to global warming and associated changes in the Indian summer monsoon circulation and the general atmospheric circulation. 

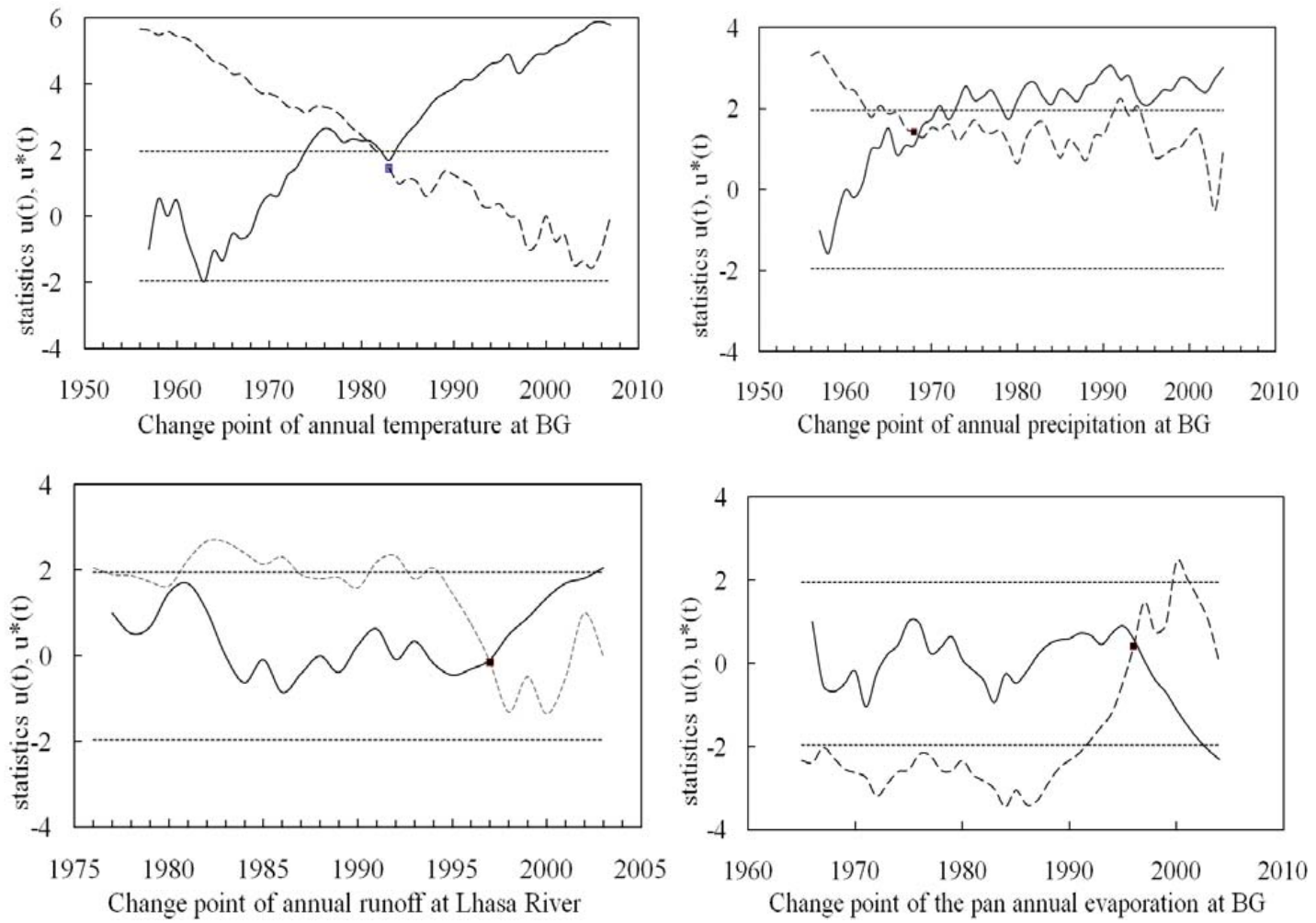

Fig. 4. Change points established using the Man-Kendall test for selected annual air temperature and precipitation (top-left and right graph), annual evaporation and runoff (lower-left and right graph) at BG for 1956-2005, and runoff data for 1976-2005 with Forward_ $u$ marked by a solid line and Backward_ $u$ by a dashed line, the dotted lines at 1.96 and -1.96 are the thresholds at significance level of $95 \%$.
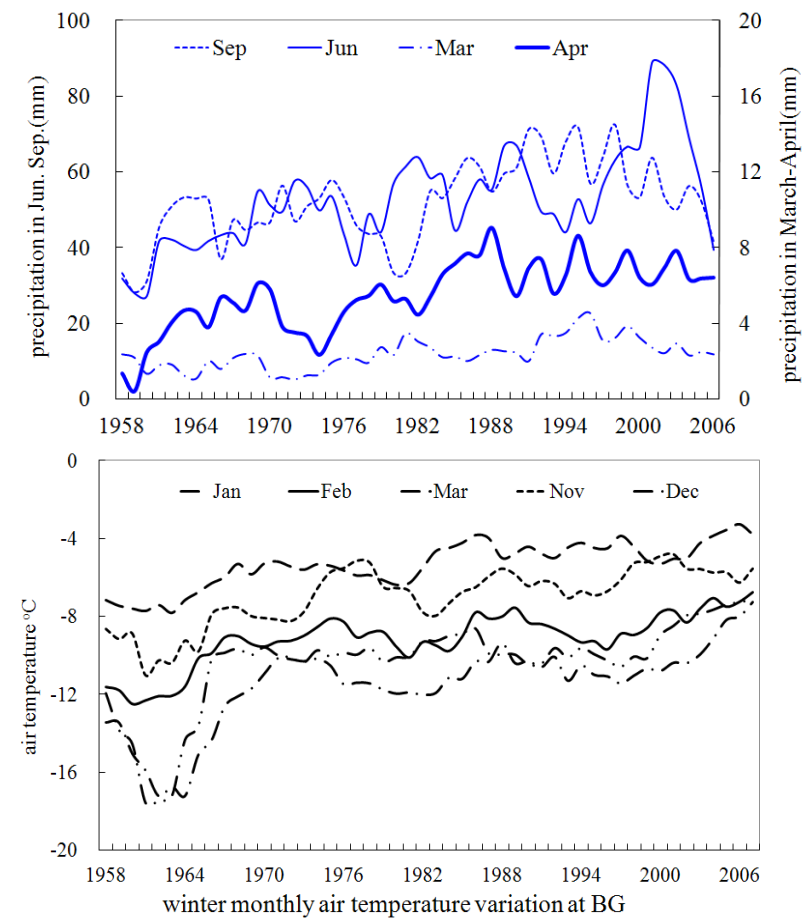

Fig. 5. Running mean (5 years) of monthly precipitation (top graph) and air temperature (bottom graph) variation at BG during 1956 to 2007.

\subsection{Hydrological changes}

Changes in snowfall and air temperature in the cold months directly affect snowmelt and accumulation, drainage, soil frost and subsurface flow in permafrost. Figure 6 and Table 2 (denoted by $Q$ ) show a few significant upward trends in streamflow during March and April for meltwater, September for rainfall runoff, and December for groundwater. These trends are significance at the $95 \%$ level or higher. The discharge in September and November to April showed significant increases of $14.2-48.4 \%$ with an averaged increase of $28 \%$, resulting in a $20.2 \%$ increase in the annual average, comparing discharge before and after the 1990 change point. However no trends were found in the summer months. It is clear that the anomalies of winter flow coincide with both the changes in temperatures, snowfall and melt duration since the 1990s.

As with air temperature, the change points showed that months with significant trends in discharges exhibited two years with abrupt changes, in 1985 for January to March and in 1996 for April, September, November, December and the annual runoff shown in Fig. 7 and Table 2. However, the change points for annual temperature, precipitation and evaporation occurred during 1984, 1969 and 1996, respectively, and the change points for monthly precipitation 


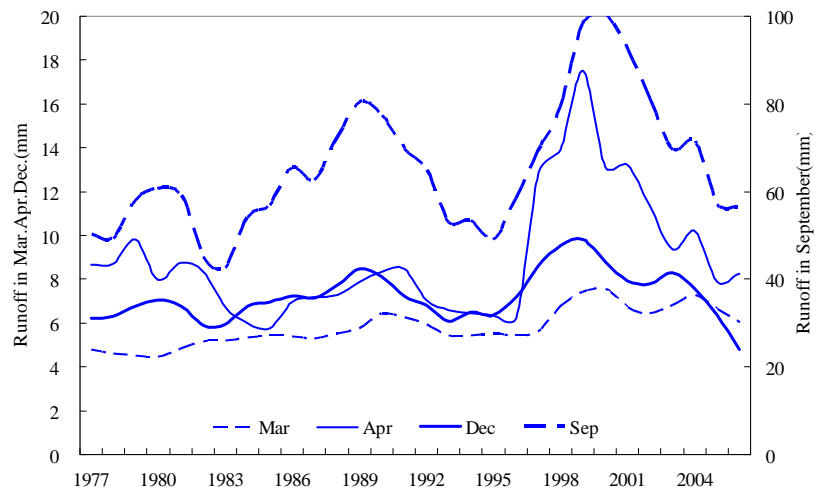

Fig. 6. Upward curves(running mean in 3 years) of monthly runoff in March, April, September and December at gauge station PD.

started in 1981 for both May and June, and in 1979 for September. The monthly pan evaporation changes became significant decreases in 2000 for both June and July and in 1995 for September. It seems the streamflow changes followed the timing in changes of annual temperature and pan evaporation. Furthermore, all streamflows in the six cold months are much more sensitive to seasonal temperatures; the trends were found in four months with a significance level of $95 \%(* *)$; and the most sensitive, with a maximum variability ( $\beta=1.308 \mathrm{~mm}$ per year), was September due to more precipitation.

\subsection{Permafrost degradation}

The depth of the active layer or of the seasonal frost in the frozen ground region is influenced by many factors such as air and soil temperature and moisture, snowpack and canopy (Nelson et al., 1997; Yamazaki et al., 1998). Generally speaking, the depth of the active layer is determined in the first instance by regional climate. Most analytical treatments have used air temperature measured at nearby locations as the primary determinant. Broad spatial patterns of temperature are related directly to macroclimate and can indeed be discerned at regional and local scales. In addition, the seasonal snowpack has significant insulating effects on the thermal regime of frozen ground and the variation in the active layer depth (Zhang et al., 1997), and as would be expected, averaging data from daily to monthly scales generally improves the correlation between air and ground temperature; this phenomenon is also due, in part, to lag effects associated with the heat conduction.

From Fig. 8, it is clear that the depth of the seasonal frost at BG station has been decreased by about $42 \mathrm{~cm}$ from $235 \mathrm{~cm}$ in the 1960 s to $193 \mathrm{~cm}$ in year 2005 , responding to the air temperature at the station described in Table 2, changes in the depth of the active layer in the studied inland lakes have occurred since the 1990s. The fluctuation of streamflow in winter, particularly in October to April, is affected by gravity drainage of the groundwater (the unfrozen water) below a depth of $200 \mathrm{~cm}$. It is relatively common for a rapid increase in the unfrozen water to occur when the ground temperature rises even to slightly below freezing temperature (e.g. 0 from $-2{ }^{\circ} \mathrm{C}$ ) according to Liu et al. (2003a, b) and Yang et al. (2002), the unfrozen water in the active layer should be transported downward into deep unfrozen soils, then drain out in the form of groundwater flow in March and April. In other words, the drainage occurrence of frost squeezing depends on the timing and depth of the lowest temperature in the active layer.

\section{Comparison with the other basins}

Increases in winter flows attributed to climate change have been observed in a number of basins with permafrost in northern Canada (Omar et al., 2006). In the permafrost region of northeast China, an abrupt warming of the regional climate with a $1.3{ }^{\circ} \mathrm{C}$ rise in the annual air temperature, coupled with a $20-40 \%$ increase in the annual precipitation, occurred in the 1990s (Liu et al., 2003a). Significant responses of winter streamflow to rising of temperatures of $2.4^{\circ} \mathrm{C}$ during December to February were observed. This was especially true for the greatest degree of warming $\left(4.4^{\circ} \mathrm{C}\right.$ in February) when runoff increased by $80 \%$ in February and by $100 \%$ in March. These responses were attributed to changes in temperature and in the depth of the active layer permitting the drainage of unfrozen water when the ground temperature is above $0{ }^{\circ} \mathrm{C}$. The depth of seasonal frost diminished by about $30 \mathrm{~cm}$ and the thickness of the active layer increased by about $40 \mathrm{~cm}$ in the permafrost in the 1990s because of the warmer climate.

In the Lena River basin in Siberia, remarkable hydrologic changes were identified during the cold season (OctoberApril) with significant increases (25-90\%) in streamflow and decreases in river ice thickness (Yang et al., 2002). During the snowmelt period (May-June), strong warming in spring led to an advance of the snowmelt season into late May and a lower daily maximum discharge in June. Changes in stream flow hydrology during the summer months (July September) were less significant than those in the winter and spring seasons. As with the results of the present study, the changes in the Lena River hydrologic regime were linked to recent climate warming and to changes in permafrost conditions.

The change in the high-elevation Nam Co Lake and the hydroclimate in central Tibet can be compared with those above. These occurred in very similar conditions of winter warming, precipitation increase, permafrost degradation and early onset of snowmelt. However, the change point for the annual mean temperature was 1983 in the lake area, earlier than that in northeast-China (1986) and later than that in the Lena River, Siberia (since the 1970s) due to its lower altitude and the plateau climate. Near the lake, all the discharge change points fall between 1985 and 1996, and all 

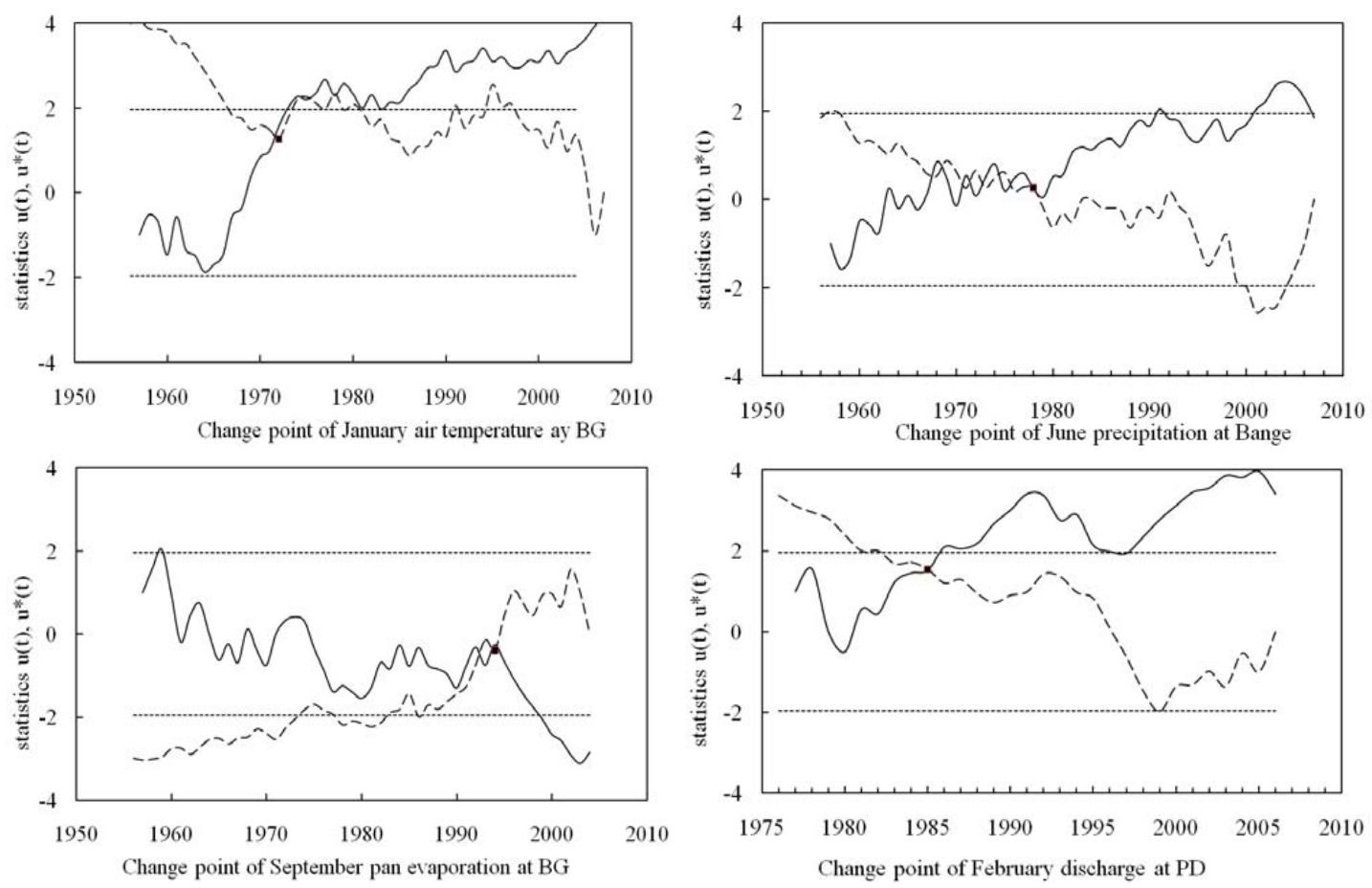

Fig. 7. Change points established using the Man-Kendall test for selected January temperature (top-left graph) and June precipitation (topright graph), September evaporation (lower-left graph) and February discharge (lower-right graph) at BG for 1956-2005, and runoff data from Lhasa River for 1976-2005, with Forward $\_u$ marked by a solid line and Backward $\_u$ by a dashed line, the dotted lines at 1.96 and -1.96 are the thresholds at significance level of $95 \%$.

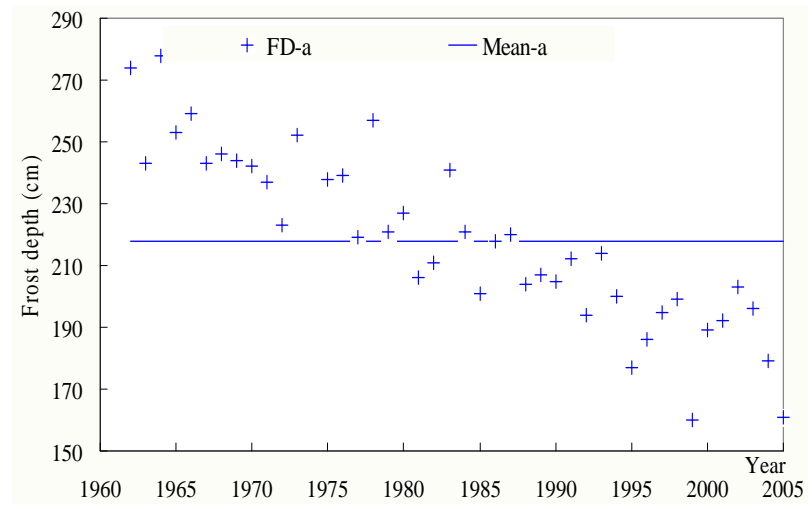

Fig. 8. Change in depth of the seasonal frost in the studied area at $\mathrm{BG}$, the fine line is the annual average and + means the depth of measured seasonal frozen ground.

the meteorological change points of the annual temperature, precipitation and the pan evaporation were localized in an early period (1983-1996). This strongly suggests an association between the two but further analysis is needed to unequivocally attribute the observed trends to climate change. For example, the relationship between the Indian monsoon and the various hydrological variables in the high-elevation lakes could be explored as this may help to provide a better explanation and prediction of their trends.
The active layer over permafrost is generally saturated during the thaw season, and thickness of the active layer in late summer and the date of the active layer freeze-up in midwinter significantly affects the hydrologic characteristics in permafrost regions. Changes in the active layer depth over permafrost directly affect potential groundwater storage and river discharge through partitioning process (Kane, 1997).

\section{Conclusions}

Climate warming indicated at the high-elevation meteorological station of BG since the 1990s has caused the dramatic expansion of the Nam Co Lake area due to both permafrost degradation and inflow increase under the background of both precipitation increase and winter warming. Dynamic and geometric evolution of a high elevation lake on the Tibetan Plateau showed the following:

a Lake growth over the Tibetan Plateau has intensified over the late 20th and early 21st centuries in response to the global warming and associated changes in the Indian summer monsoon. However, the lake change trends have not been well documented in China. Because of their sizes, considerable variability may exist in the highland and the lowland lakes across the country. 
b Upward trends in late autumn and early winter temperatures, spring and autumn precipitation (snowfall) and downward trends in summer pan evaporation were found at a high-elevation meteorological station in central Tibet. However, many of these trends were not significant at the $10 \%$ level and their seasonal coherence was generally weak, but strong in an annual scale. The latter may be due to the retarding effect of permafrost (the active layer and area) and local meteorological conditions such as wind, which can play a significant role during the freezing-thawing processes.

c Significant increasing trends in the autumn, winter and spring flow were found at the highest gauged station near central Tibet, though change points in earlier years dominated over the period of analysis. Several trends were significant at the $1 \%$ level and their temporal coherence was strong. Tibet showed consistent trends toward earlier snowmelt dates over all 30-year periods. The spatial patterns were consistent with changes in spring snow cover duration derived from the NOAA dataset.

$\mathrm{d}$ The trends observed in the lake growth are consistent with a positive water balance (e.g. permafrost degradation and snow cover compared with evaporation) and provide further evidence of the enhanced winter and spring warming that began over the Tibetan Plateau during the late 20th century.

Finally, the results of this study allow for future, regionally focused investigations on the response of lake growth to climate change over longer time periods and in relation to the large-scale Indian monsoon and the plateau climate/teleconnections. The recent availability of lake growth on databases such as China Lake DataBase (www.lake. csdb.cn) and the CCDD (http://wdcdgg.westgis.ac.cn) on the China Cryosphere Database will facilitate these types of investigations.

Acknowledgements. This study was supported by the "National Basic Research program of China" (No. 2005CB422003), and jointly by the National Natural Science Foundation of China (40571037 \& 40561002), the FP-6th project "Brahmatwin" (036952) of the EU and the "the Talent Project" of Chinese Academy of Sciences. The authors would like to thank Bill Isherwood, USGS, USA for undertaking substantial editorial revision and Daqing Yang of Water and Environmental Research Center, University of Alaska, Fairbanks Alaska, USA and Lu Zhang from Cooperative Research Centre for Catchment Hydrology and CSIRO Land and Water, Canberra, Australian for their constructive comments.

Edited by: S. Carey

\section{References}

Burn, D. H. and Elnur, M. A. H.: Detection of hydrologic trends and variability, J. Hydrol., 255, 107-122, 2000.

Chen, S., Liu, Y., and Thomas, A.: Climate change on the Tibetan plateau: potential evapotranspiration trends from 19612000, Climatic Change, 76, 219-319, 2006.

Duguay, C. R., Prowse, T. D., Bonsal, B. R., Brown, R. D., Lacroix, M. P., and Ménard, P.: Recent trends in Canadian lake ice cover, Hydrol. Process., 20, 781-801, doi:10.1002/hyp.6131, 2006.

Dorava, J. M. and Milner, A. M.: Role of lake regulation on glacierfed rivers in enhancing salmon productivity: the Cook Inlet watershed, south-central Alaska, USA, Hydrol. Process., 14, 31493159, 2000.

Du, J.: Recent change of Air temperature for 40 years in QinghaiXizang Plateau. Acta Geographica Sinica, 56(6), 682-690, 2001 (in Chinese).

Du, J. and Ma, Y.: Climatic trend of precipitation over Tibetan Plateau From 1971 to 2000. Acta Geographica Sinica, 59(3), 375-382, 2004 (in Chinese).

Gibson, J. J., Prowse, T. D., and Peters., D. L.: Hydroclimatic controls on water balance and water level variability in Great Slave Lake, Hydrol, Process., 20, 4155-4175, doi:10.1002/hyp.6424, 2006.

IPCC Climate Change: The physical science basis. Contribution of working group I to the fourth assessment report of the Intergovernmental Panel on Climate Change, edited by: Solomon S., Qin, D., Manning, M., and Chen, Z., 2007.

Kane, D. L.: The impact of Arctic hydrologic perturbations on Arctic ecosystems induced by climate change, in: Global Change and Arctic Terrestrial Ecosystems, edited by: Oechel, W. C., Springer-Verlag, Ecological Studies, 124, 63-81, 1997.

Kendall, M. G.: Rank Correlation Measures, Charles Griffin, London, 1975.

Kundzewicz, Z. W. and Robson, A. J.: Change detection in hydrological records - a review of the methodology, Hydrolog. Sci. J., 49(1), 7-19, 2004.

Liu, J. S., Hayakawa, N., Lu, M. J., Dong, S. H., and Yuan, J. Y.: Hydrological and geocryological response of winter streamflow to climate warming in northeast China, Cold Reg. Sci. Technol., 37, 15-24, 2003.

Liu, J. S., Hayakawa, N., Lu, M. J., Dong, S. H., and Yuan, J. Y.: Winter streamflow, ground temperature and active-layer thickness in northeast China, Permafrost Periglac., 14(1), 11-18, 2003.

Liu, J. S., Wang, S. Y., and Huang, Y. Y.: Effect of climate change on runoff in a basin with mountain permafrost, Northwest China, Permafrost Periglac., 18, 369-377, 2007.

Mann, H. B.: Non-parametric tests against trend, Econometrica, 13, 245-259, 1945.

Marsh, P. and Neumann, N. N.: Processes controlling the rapid drainage of two ice-rich permafros-dammed lakes in NW Canada, Hydrol. Process., 15, 3433-3446, doi:10.1002/hyp.1035, 2001 
Mielko, C. and Woo, M. K.: Snowmelt runoff processes in a headwater lake and its catchment, subarctic Canadian Shield, Hydrol. Process., 20, 987-1000, doi:10.1002/hyp.6117, 2001.

Mitchell, J. M., Dzezerdzeeskii, B., and Flohn, H.: Climatic change, WMO Tech. Note, WMO NO, 195, TP-100, Geneva, 1996.

Nelson, F. E., Shiklomanov, N. I., and Mueller, G. R.: Estimating active layer thickness over a large region: Kaparuk river basin, Alaska, USA, Arctic Alpine Res., 29, 367-378, 1997.

Omar, I. A. A. and Burn, D. H.: Trends and variability in the hydrological regime of the Mackenzie River Basin, J. Hydrol., 319, 282-294, 2006.

Qin, D. H., Chen,Y. Y., and Li, X. Y.: Climate and environmental changes in China, Sci. Press, Beijing, 6-418, 2005.

Shi, Y. F., Shen, Y. P., Ding, Y. J., and Zhang, G. W.: An Assessment of the Issue of Climatic shift from the warm-dry into warm-wet in Northwest China, Meteorology Press, Beijing, 3-55, 2003.

Singh, N. and Sontakke, N. A.: On Climatic fluctuations and environmental change of the Indo-Gangetic Plains, India, Climatic Change, 52(3), 287-313, 2002.

Sneyers, R.: On the Statistical Analysis of Series of Observation, Tech. Note 143, WMO No.415, Geneva, 192 pp., 1990.
Wang, S. L., Zhao, X. F., Guo, D. X., and Huang, Y. Z.: Response of frozen ground to climatic change in the Qinghai-Xizang Plateau, J. Glacio. \& Geocryo., 18, 157-165, 1996, (in Chinese).

Wang, C. H. and Dong, W. J.: Abnormal characteristics of interannual variation in seasonally frozen ground, Qinghai-Xizang Plateau, Acta Geographica Sinica, 56(5), 523-531, 2001 (in Chinese).

Wang, S. M. and Duo, H. S.: Records of China Lake, Sci. Press, Beijing, 512 pp., 1998 (in Chinese).

Yamazaki, T., Kondo, J., and Nishida, A.: Seasonal frost depth of grounds with the bare surface, snow cover and vegetation, Japanese Journal of Snow and Ice, 60, 213-224, 1998 (in Japanese).

Yang, D. Q., Kane, D. L., Hinzman, L. D., Zhang, X., Zhang, T. J., and Ye, C.: Siberian Lena River hydrologic regime and recent changes, J. Geophys. Res., 107(D23), 4694, doi:10.1029/2002JD002542, 2002.

Zhang, T. J., Osterkamp, T. E., and Stamnes, K.: Effect of climate on the active layer and permafrost on the Northern slope of Alaska, USA, Permafrost Periglac., 8, 45-67, 1997.

Zhou, Y. W., Guo, D. X., Qiu, G. Q., and Cheng, G. D.: Geocryology in China, Sci. Press, Beijing, 218 pp., 2000. 